\title{
On the Sound Environment of the City of Puerto Vallarta, Jalisco, Mexico
}

\author{
R. R. Boullosa* ${ }^{* 1}$ C. Alvarado Z. ${ }^{2}$ \\ ${ }^{1,2}$ Laboratorio de Acústica y Vibraciones \\ Centro de Ciencias Aplicadas y Desarrollo Tecnológico, \\ Universidad Nacional Autónoma de México. Circuito Exterior, \\ Ciudad Universitaria, Coyoacán CP 04510, México D.F. \\ *ricardo.ruizb@gmail.com \\ ${ }^{2}$ Grupo de Espacios y Sistemas Interactivos para la Educación, \\ Centro de Ciencias Aplicadas y Desarrollo Tecnológico, \\ Universidad Nacional Autónoma de México. Circuito Exterior, \\ Ciudad Universitaria, Coyoacán CP 04510, México D.F.
}

\begin{abstract}
An exploration of the sound environment in the city of Puerto Vallarta, Jalisco, Mexico, is presented. A series of interviews were held with 19 residents, of which 7 were undergraduate students, related to the perception of sound in or around places of different zones in the so-called "Viejo Vallarta" ("Old Vallarta").

The purpose was twofold, firstly, to explore the ideas people have relating to the sounds they hear in the city -and in general, the ideas they have relating to peace and tranquility and its possible relation with the sound environment-; secondly, to identify some zones or places that have a particular sound environment - positive or negative. Natural sounds emerged as an important part of the sound identity of the Vallarta region and they seem to be highly appreciated even when the sound levels are high. Sounds related to nature emerged in all interviews: bird calls, sound of wind rustling through trees, sound of breaking sea waves, etc. The interviewees identified places or zones with a negative sonic identity due to disagreeable or high intensity sounds; traffic flow, and mostly the urban bus, is to be blamed for in the main (some mentioned radios at high volume). A series of sound levels (dBA re $20 \mu \mathrm{Pa}$ ) at three different times of the year: February, April, and October, 2009 were measured in some locations mentioned by the interviewees. The average sound levels found on those locations considered as having a disagreeable identity were the highest.
\end{abstract}

Keywords: sound identity, sound environment perception, urban noise.

\section{RESUMEN}

Se presenta un estudio que constituye básicamente una exploración del ambiente sonoro de Puerto Vallarta, Jalisco, México. Se entrevistaron 19 de sus residentes -siete eran estudiantes universitarios-, para detectar la percepción de sonidos en o alrededor de diferentes zonas del llamado Viejo Vallarta.

El estudio tuvo doble propósito: primero, explorar las ideas que las personas tienen con respecto a los sonidos que escuchan en esa ciudad y, en general, las ideas que tienen acerca del concepto paz y tranquilidad y su posible relación con el ambiente sonoro; segundo, identificar algunas zonas o lugares con un ambiente sonoro particular positivo o negativo-. Los resultados muestran que las personas poseen una clara comprensión de los ambientes de algunos lugares; existen varias locaciones con identidad sónica específica. Los sonidos naturales son parte importante de la identidad sonora de la región de Vallarta y son ampliamente apreciados aun cuando sus niveles sean elevados. Una mención constante de sonidos relacionados con la naturaleza emergió en todas las entrevistas: canto de las aves, sonidos del viento y del oleaje del mar, etc. Se identificaron lugares o zonas con una identidad sonora negativa, debido a sonidos desagradables o de elevada intensidad, y al flujo del tráfico, principalmente por camiones urbanos. Se midieron los niveles de sonido (dBA re $20 \mu \mathrm{Pa}$ ) en febrero, abril y octubre de 2009, en algunas de las locaciones de Puerto Vallarta mencionadas por las personas entrevistadas. 


\section{Introduction}

Several studies relating to the measurement of sound and some relating to noise nuisance in the population were done in the last decades in many European countries, and in Canada, in Japan and the United States (Canneli, 1974; Fidell, 1978; Brown and Lam, 1987; Barrigón et al., 2002). In México a study was done in a small area of México City (Boullosa and Pérez, 1987), recently a study of reaction to noise and other factors of the environment was done near the same area (Germán, 2008), but there are no accessible studies, if any, undertaken in other cities in this country. The results of traditional studies show that the correlation between nuisance and sound levels is not always high enough to explain the results, especially when sound or noise is not produced by transport vehicles. In general the correlation is high for motor traffic noise (European Commission, 2008). The cause of this low correlation for other types of sounds is attributed to the overlooking of other variables that are part of the psychological reaction of the population to the sound environment. There is another dimension related to noise, and that would be the perception by the people subjected to it, even more, the concept of " intention" is central to the problem, that is wanting or not wanting to listen to a given sound. The perception of the presence of a sound is related to its contextual attributes, be them social, cultural or topological in a given urban environment. Most of the cited studies have not considered this aspect of the problem. Most of the regulations -in places where they exist- focus mainly on the measurement of maximum sound levels and therefore bypass the human perception of sound. This perception rests mainly in the meaning that a given population gives to the sounds heard, in relation to the source generating the sound, which always occurs in a given context (López Barrio and Carles, 1995).

The conjunction of an emotional and aesthetic view and intellectual knowledge was initiated by $A$. von Humboldt, who in the beginnings of the XIX century wrote about the "natural scenes" in which he portrayed, among other things, the sound scenes he "observed" in his trips to México and other Latin American countries; he described real soundscapes, sound memories, etc. (Velasco,
2000) ${ }^{1}$. More than a century later, several researchers from various countries have given new approaches, from the 1970s on, to the sound environment and noise in rural and urban environments. Schaffer (1977) proposed the soundscape concept, considering that when humans enter an environment they have an effect on it, they become composers as in a musical composition in which the population actively participates, consciously or unconsciously. He also established acoustic ecology as a new discipline, and the necessity of preserving certain sonic spaces that are important for the communities, be them natural or built by man. The soundscape concept is somewhat general especially when applied to urban noise. It has more application in landscape design. Augoyard (1999) proposed the sound effect concept that describes a particular sound perception as a result of certain physical conditions (such as the nature of the source, the acoustics of the place, etc.), cultural and social settings, and certain perception mechanisms. These effects define or condition certain soundscapes and are an integral part of its subjective evaluation. A well-known example of a sound effect is reverberation (the persistence of sound in a room -or in a narrow street limited by buildings in a city-, after the source stops emitting sound).

In Switzerland, the sound identity concept was used (Amphoux 1993) in the study of three Swiss cities; this concept emphasizes the positive aspects of sound considering the types of sources, sound levels, time distribution of them, periodicity, etc. A city has characteristic places or zones in terms of types and levels of sound and noises and social concomitant activities; it is not homogenous. The concept takes into account cultural issues,

\footnotetext{
The mexican poet M. J. Othón (1858-1906), was a master of dynamic sonic landscape portrayal -this time in the realm of poetry- and of descriptive natural scenes (panoramic sonic shots), keeping a certain aesthetic distance. A brilliant example of this would be the poem "Himno de los bosques" (Hymn of the woods), a small fragment follows "...entre las hojas de la verde caña/ se escucha el agudísimo zumbido/ del insecto apresado por la araña,/ las ramas secas quiébranse al ligero/ salto de las ardillas, su chasquido/a unirse va con el golpeo bronco/ del pintado y nervioso carpintero/ que está en el árbol taladrando el tronco ..."
} 
uses of space and associated ambiances or events that are part of the culture and lore of the place (for example the sound events that occur in a given festivity in many towns in Latin America), which are left aside in the majority of noise studies. That author proposes for a sound ambiance three dimensions: acoustic, topological (relating to the organization of urban space) and cultural.

The concept of "ambiance" (from ambiens going around, surrounding) originated in the XIX century (Augoyard, 2005) and includes all that is involved in the perception by all senses, that is, the light, sound, odors, colors, constructions, traffic, even the state of a place, weather, for example. An element of time is involved as this ambience changes in time. In general, it includes "all material and moral atmosphere that surrounds a place" (Amphoux, 2004), but we might add that "is" part of a place, in particular urban public spaces, where people immerse and get surrounded by the ambience. The different factors that make up the ambience can interact and contribute to or inhibit the reaction of a human to other factors; for example, a beautiful sight or an odor might inhibit the perception of a given sound or a collection of sounds.

Also, in relation to sound, the reaction of the population or an individual to the sound or sonic ambiance of a given place also depends, among other factors, on the compliance of the place to certain expectations. A given place is identified by those activities that produce uniquely identifiable sounds: a park is (or should be) quiet and a place of tranquility; a market is identified with the sounds of vendors selling their produce, etc. It constitutes a specific and complex atmosphere that changes in time and sometimes is cyclic -in the course of a day, a week, or a season-. The sound identity might be conscious in certain part of the population or some individuals but it might be hidden and unconscious in others, as it was corroborated in our case.

Puerto Vallarta is known for being a resort and an international retirement destination -mostly for Canadians and US citizens-. It has nearly 350,000 inhabitants, but the number is growing, and with it, transportation and vehicle traffic has had a concomitant increase. The relation between sound and tranquility has not been investigated in Vallarta -or other cities in Mexico. In a study relating to the quality of life in the Puerto Vallarta region (Massam et al., 2003), whose purpose was to examine the impact that tourism has on the quality of life, individuals were asked to indicate the importance and satisfaction levels for a set of indicators relating to quality of live. Among other findings, the indicator peace and tranquility had a 4.7 score in a 5 point scale, the other most important indicators were health, family, water, air, and education (5 indicated very high importance and 1 very low importance). Noise was among the least important indicators (along with shopping, and holidays).

The present study was undertaken in order to investigate the perception of sound in general, as well as to identify specific sonic ambiences perceived as positive or negative-, which are characteristic of Puerto Vallarta. A series of interviews were held related to the perception of sound in or around places of different zones in the so-called "Viejo Vallarta" ("Old Vallarta"). The purpose was twofold, firstly, to explore the ideas people have relating to the sounds they hear in the city -and in general the ideas they have relating to peace and tranquility and noise-; secondly, to identify some zones or places that have a particular sonic environment.

We give some results and discussions relating to the perception and description of sounds and places that led to the sonic identities. Some measurements of sound levels, at different times of the year were made. These measurements helped in the analysis of the responses given by the interviewees.

\section{Procedure}

The methodology applied was non-standard and covered two aspects:

A) Socio-cultural interviews.

Using the memories of places and sound events heard in them, the interviewees disclosed through their description sounds that characterize a given place. A questionnaire (5 questions) was applied to 12 (7 men, 5 women) non-student residents and 7 undergraduate (Centro Universitario de la Costa CUC) students (5 women, 2 men). The analysis of 
the answers to the questions posed by the interviewer identified specific places with a sonic identity. The perception of peace and tranquility was investigated by asking the question: What is peace and tranquility to you? This question was posed to nine people (the 7 CUC students) and two nonstudents. The overall results are given in graphs and a table of individual responses to a given place.

\section{B) Acoustic measurements}

Sound Pressure Levels (SPL), or sound levels, in $\mathrm{dBA}$ re $20 \mu \mathrm{PA}$ (the dBA weighting is an electronic weighting that simulates the logarithmic response of the ear), were measured in different months (February, April, and October, 2009), in a total of 8 points and different times of the day, not always at the same hours. A sound level meter CE HER-800 type 2/IEC651 previously calibrated was used. Sound levels were annotated by hand, holding the noise meter at around $1.20 \mathrm{~m}$ from the ground and $0.40-0.50 \mathrm{~m}$ in front of the person measuring; data were annotated every 30 seconds or every minute. All locations were in Puerto Vallarta and some measurements corresponded to locations mentioned in the interviews. The general conditions were sunny, temperature between 22$35^{\circ} \mathrm{C}$, light air wind.

The measurement points were located at (1) Las Glorias beach, a relatively calm beach at a short walk from the City Center, (2) in front of the Rosita Hotel (a historical landmark in the city) in an urban park with a water fountain, (3) at the Malecón, near the Hippocampus statue (another landmark) - a busy street with many restaurants, bars, stores etc., facing the beach, (4) at the town center- at the municipal government building in a very small park, (5), busy Colombia street in the City Center, (6) residential street near the beach; (7) busy streets corner, Juárez \& Galeana; (8) Perhaps the busiest main avenue, F. M. Ascencio Av, corner with Prisciliano S. running for several kilometers- in the hotel zone, through the airport, etc. , were main dense traffic flows into the city.

\section{Analysis and Results}

In response to the question: "Can you think of specific places in Puerto Vallarta that have a particular sound or characteristic sonic ambiance?" several places with a given sound ambiance were mentioned (30 places, but some were mentioned only once and included places that are not in old Vallarta). The ten locations in old Vallarta, which were mentioned at least 3 times vs. the number of times it was mentioned (by different interviewees), is shown in Figure 1. In what follows, only some of the locations, their sound levels and responses to some of the questions are analyzed.

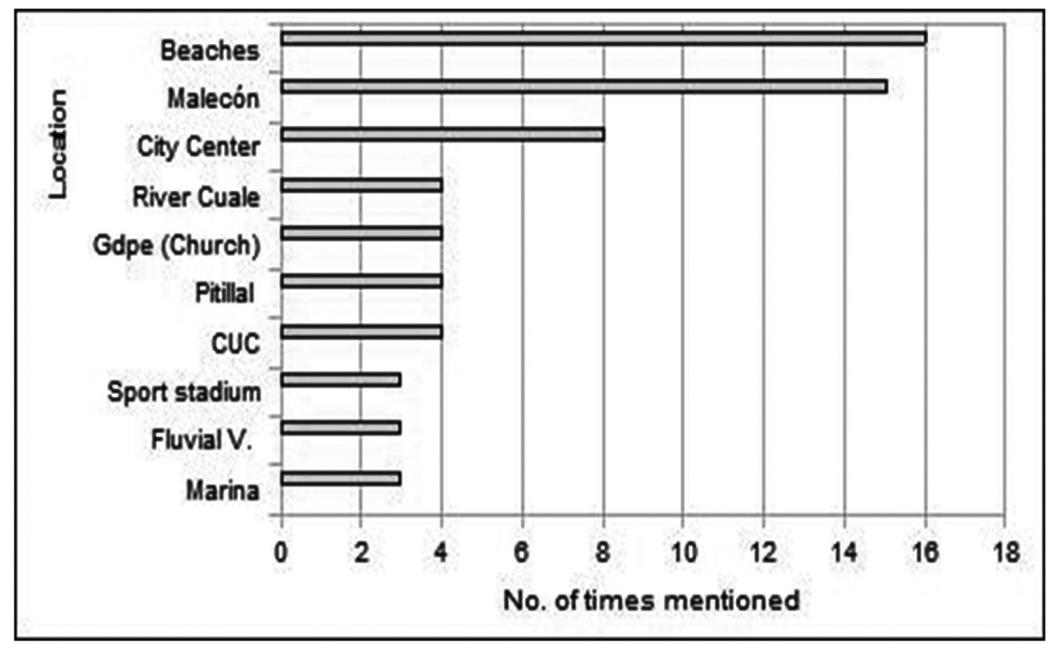

Figure 1. The ten most mentioned locations as having a particular sound environment vs. the number of times they were mentioned by all interviewees. 


\begin{tabular}{|c|c|c|c|c|c|c|c|c|c|c|c|c|c|c|c|c|c|c|c|}
\hline Location & [1] & [2] & [3] & [4] & [5] & [6] & [7] & [8] & [9] & [10] & [11] & [12] & [13] & [14] & [15] & [16] & [17] & [18] & [19] \\
\hline Cuale river & A & & & & & & & & A & & A & & & & & & & A & \\
\hline Malecón & D & M & A & A & A & D & M & A & A & & M & M & A & & D & & & D & D \\
\hline Beaches & A & A & M & A & M & A & A & & A & & A & A & A & A & A & A & & M & A \\
\hline Stadium & & M & & & & & & & & & & & A & & & & A & & \\
\hline $\begin{array}{l}\text { Hotel } \\
\text { zone, Las } \\
\text { Glorias" }\end{array}$ & & D & & & & & & M & & & & & & & & & & & \\
\hline $\begin{array}{l}\text { Residential } \\
\text { Fluvial } \\
\text { Vallarta }\end{array}$ & & & A & & & & A & & & & & & & & & & & & A \\
\hline $\begin{array}{l}\text { Church/park } \\
\text { Nuestra } \\
\text { Señora de } \\
\text { Guadalupe }\end{array}$ & & & A & & A & A & & & A & & & & & & & & & & \\
\hline City Center & & & & & D & D & & D & D & A & & & & D & & & D & & D \\
\hline $\begin{array}{l}\text { Marina } \\
\text { Vallarta }\end{array}$ & & & & & & & & A & & A & & M & & & & & & & \\
\hline $\begin{array}{l}\text { Hills } \\
\text { facingcity } \\
\text { center }\end{array}$ & & & & & & & & & & & A & & & & & & & A & \\
\hline Airport & & & & & & & & & & & A & & & & & & D & & \\
\hline $\begin{array}{l}\text { Street, F. } \\
\text { Medina A. }\end{array}$ & & & & & & & & & & & & D & D & & D & & & & D \\
\hline Disco & & & & & & & & & & & & & & D & & A & & & \\
\hline CUC & & & & & & & & & & & & & & & A & M & A & & M \\
\hline $\begin{array}{c}\text { Fco. Villa } \\
\text { Av. }\end{array}$ & & & & & & & & & & & & & & & & D & A & & \\
\hline
\end{tabular}

Table 1. The individual rating (A: agreeable, D: disagreeable, M: mixed reaction, sometimes agreeable, at other times disagreeable) in the responses to the question: "Can you think of specific places in Puerto Vallarta that have a characteristic sound or sound ambience?". The first column identifies the place or location; the next columns identify the individual responses numbered 1 to 19 in the first row. Locations mentioned only once are not shown. 
On the Sound Environment of the City of Puerto Vallarta, Jalisco, Mexico, R. R. Boullosa / 430-442

\begin{tabular}{|c|c|c|c|c|c|}
\hline Interviewee & Age(Years) & Gender & $\begin{array}{l}\text { Years of } \\
\text { Residence }\end{array}$ & Occupation & $\begin{array}{l}\text { Date of } \\
\text { capture }\end{array}$ \\
\hline$[1]$ & $26-35$ & $\mathrm{~F}$ & 16 & $\begin{array}{l}\text { Restaurant } \\
\text { manager }\end{array}$ & 8-07-2009 \\
\hline [2] & $26-35$ & $\mathrm{~F}$ & 35 & Hair stylist & $8-07-2009$ \\
\hline [3] & $26-35$ & $\mathrm{~F}$ & 10 & Condo manager & 8-07-2009 \\
\hline [4] Canadian & $56-65$ & $M$ & 3 & $\begin{array}{l}\text { Community } \\
\text { service }\end{array}$ & $8-07-2009$ \\
\hline$[5]$ & $26-35$ & $\mathrm{~F}$ & 2 & House cleaner & $8-07-2009$ \\
\hline [6] & $36-45$ & $\mathrm{~F}$ & 13 & $\begin{array}{l}\text { Hydrology } \\
\text { department }\end{array}$ & $10-07-2009$ \\
\hline [7] & $56-65$ & $\mathrm{~F}$ & 8 & Housewife & 10-07-2009 \\
\hline [8] & $26-35$ & $M$ & $\begin{array}{l}3 \text { months } \\
\text { residence }\end{array}$ & Architect & 8-10-2009 \\
\hline [9] & $36-45$ & $M$ & 2 & Accountant & 8-10-2009 \\
\hline [10] & $36-45$ & $M$ & 10 meses & Real State & $8-10-2009$ \\
\hline [11] & $46-55$ & $\mathrm{~F}$ & 20 & $\begin{array}{l}\text { High school } \\
\text { teacher }\end{array}$ & 8-10-2009 \\
\hline [12] & $26-35$ & $M$ & 6 & $\begin{array}{l}\text { Private security } \\
\text { (1-year college } \\
\text { attendance) }\end{array}$ & 8-10-2009 \\
\hline [13] & $18-25$ & $M$ & 18 & $\begin{array}{c}\text { Student } \\
\text { (Multimedia) }\end{array}$ & $9-10-2009$ \\
\hline [14] & $18-25$ & $\mathrm{~F}$ & 2 meses & $\begin{array}{c}\text { Student } \\
\text { (Administration) }\end{array}$ & $9-10-2009$ \\
\hline [15] & $18-25$ & $\mathrm{~F}$ & 6 & $\begin{array}{c}\text { Student } \\
\text { (Administration) }\end{array}$ & $9-10-2009$ \\
\hline [16] & $18-25$ & $F$ & 19 & $\begin{array}{l}\text { Student } \\
\text { (Tourism) }\end{array}$ & $9-10-2009$ \\
\hline [17] & $18-25$ & $\mathrm{~F}$ & 20 & $\begin{array}{l}\text { Student } \\
\text { (Tourism) }\end{array}$ & $9-10-2009$ \\
\hline [18] & $18-25$ & $\mathrm{~F}$ & 20 & $\begin{array}{l}\text { Student } \\
\text { (Tourism) }\end{array}$ & $9-10-2009$ \\
\hline [19] & $18-25$ & $M$ & 21 & Student (Law) & $9-10-2009$ \\
\hline
\end{tabular}

Table 2. Individuals identified by age, sex, and if student or not student, etc. 
Table I shows the places mentioned in the individual answers to the question: Can you think of specific places in Puerto Vallarta that posses a particular sound or characteristic sound ambience?, rated in terms of agreeability (A: agreeable, D:disagreeable, and M: mixed feelings).

In Table II, individuals are identified by age, sex, and if student or not student, etc.

Some of the answers to the questions: "Is there a sound (s) characteristic of each of the places you mentioned that has a special meaning to you?", "What do you like or dislike of the place you mentioned?" are presented. In relation to the beaches (playas)- the most mentioned, general, location -some of the answers were "I like to walk on the beach and hear the waves breaking in the rocks", "The sound of the wind and the waves is relaxing", "The 'Twins'... beach is relaxing because of the waves, the wind, the birds", "Tranquility. ..Especially those far away...", "You can hear the pelicans and the sound of the waves". "Relaxing due to sound of the waves, but I dislike the barking of dogs, and the beach vendors". "In... beach you can hear the sound of birds, the wind in the trees, but not on weekends". In general, the answers showed that people like the natural sounds related to the beach and dislike the noise of the people on weekends, or caused by any other activity.
Sound Pressure Levels (SPL, A weighting)), also referred to as sound levels, were measured at a point in Las Glorias beach, in the morning, these are shown in Figure 2. The lines joining the points are there for the purpose of clarity, they do not represent data points. The average sound level of a typical run of measurements was $57 \pm 6 \mathrm{dBA}$. The standard deviation of the measurements is shown as an error bar on all the graphs. The maximum values were around 65-70 dBA and the minimum around $50 \mathrm{dBA}$, in typical runs of measurements; in a very calm day with no wind. The maximum levels were associated with the breaking of the sea waves.

The Malecón, a busy street on the beach in the city center, is a place where many bars, cafés, restaurants, galleries, and stores, are located. It is a typical pedestrian street where people especially tourists- gather. There is a heavy traffic flow all day long. The sound levels were measured near an emblem of the place: the Hipocampo (Hippocampus) statue. The sound levels vs. time are shown in Figure 3. The average sound level, in this instance, was $72 \pm 6$ $\mathrm{dBA}$. The maximum level was $89 \mathrm{dBA}$ and the minimum $60 \mathrm{dBA}$. The average sound level for the three dates was $68 \pm 5 \mathrm{dBA}$, at around $12 \mathrm{~h}$.

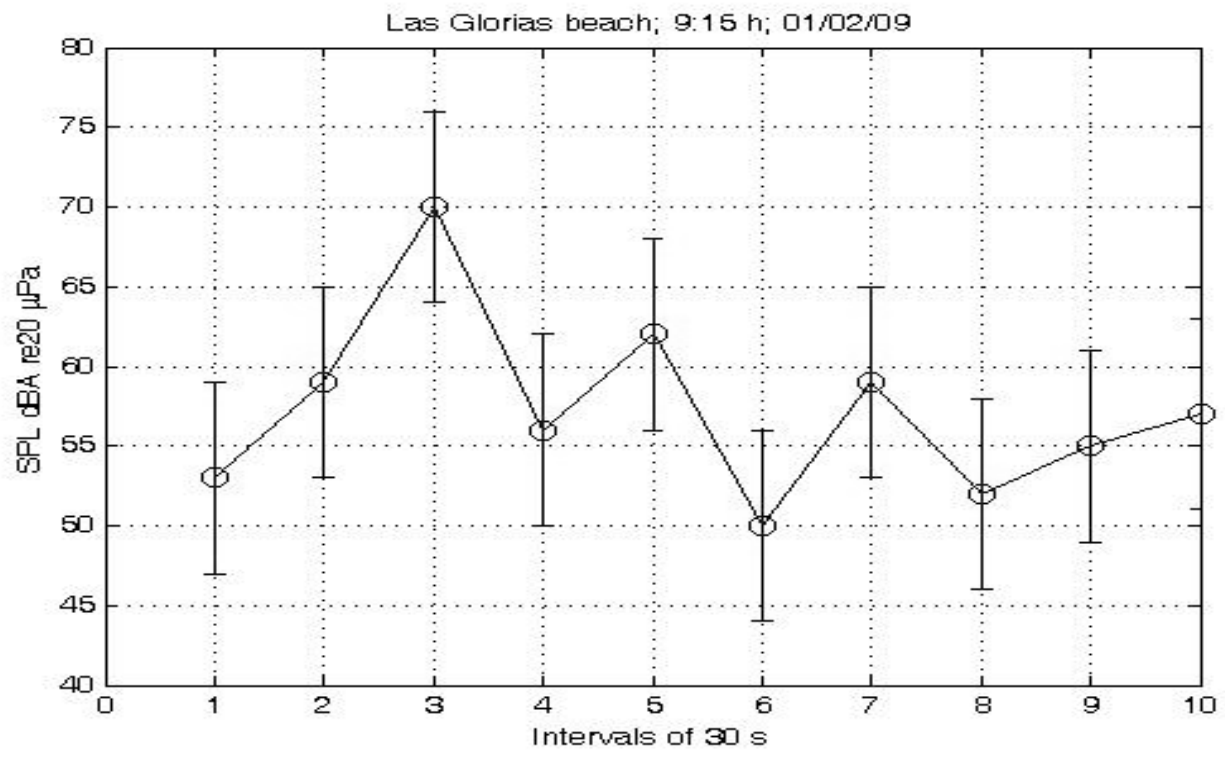

Figure 2. Typical sound levels measured at a point in Las Glorias beach. A few blocks from the city center. The standard deviation of the measurements is shown by the error bar on each point. 
The commentaries about this location have both positive and negative perceptions. To some people it is acceptable at some times, at others not: "I like it during the day, but not at night because of the noise in bars, and restaurants; I don't like on weekends". A middle-aged woman said: "It stresses me out because of all that irritating noise from cars and buses (with high volume music all the time, vendors with loudspeakers ...I don't like the firecrackers ... the inhabitants of Vallarta seldom go to this place... they prefer the outskirts to relax", people like it because of the variety of activities that take place in there, as another middle-aged women said: "Very pleasant ... all those music festivals with artists and singers..". Or a Canadian resident saying: "It is an agreeable place because of the sound of people, the voice of tourists, high-volume music"..," I don't mind the sound of bars and discotheques at night", "It is an agreeable place, the sounds of people, the tourists, ... propaganda, the sound -not noise- from the bars and discotheques".

The sound pressure levels typical of the city park (Plaza del Ayuntamiento) are shown in Figure 4. This very small park is surrounded on two sides by heavy traffic flow -mostly urban buses running through the city center. The average level was around $67.5 \pm 4 \mathrm{dBA}$. The peak values reflect the passage of buses and traffic flow in the vicinity of the park. The level is relatively high -the European Commission accepts a maximum average value of $55 \mathrm{dBA}$ for urban parks ${ }^{2}$. Nevertheless, many of the events that appear as peaks in the graph were caused by the chattering of the birds -this park has a flock of numerous birds (mostly great-tailed grackles: Quiscalus Mexicanus), as well as the periodical ringing of the bells in the church -in front of the park, at one- (small) street-length distance, children playing or sounds of people talking. The average sound level for the three dates was $66 \pm 4$ $\mathrm{dBA}$ at around $13 \mathrm{~h}$.

Figure 5, corresponding to a busy street with many city buses, cars, and pick-ups, shows a typical run

2 The index used is strictly dBA Leq, which is the continuous equivalent sound level (A weighted) that has the same average energy as the fluctuating measured noise, in a given time interval (the time, interval can be seconds or several hours) if it is $24 \mathrm{~h}$ the night hours are penalized giving them a mathematical weight. of measurements. The higher levels reached nearly $90 \mathrm{dBA}$. The average value was around 76 $\pm 8 \mathrm{dBA}$. More than $90 \%$ of the higher levels corresponded to the noise of buses, and pick-ups sometimes, with the added sound of radios or CDs played at high volume in the cabins. The average level for the three dates was $78 \pm 8 \mathrm{dBA}$, in between $(12-13) \mathrm{h}$. The peaks reflect the periodical nature -nearly $1 \frac{1}{2} \mathrm{~min}$ - of the traffic flow due to the traffic lights. The lowest levels reach the noise background -when there is no traffic flow- when at moments there was not a single bus or vehicle in the vicinity of the measuring point.

Along this street there is a sonic effect: reverberation, due to the narrowness of the street. The buildings, though not very tall on both sides of the street, cause reflections between them; the level of sound rises due to the accumulation of sound reflections. This effect was clearly perceived by the authors but not investigated or measured in any way. The same buses circulating in a nearby and wider street and with lower buildings, gave the impression of producing rather lower sound levels in that street.

Only one person referred to this area as a positive location "I like to hear the voices .... from the people doing their activities". All the rest were negative, some of which were "It is a nuisance; it bothers me because of the noise from the city buses. I dislike the noise from the accelerating buses, because the streets are narrow and cobblestoned". "It is a disagreeable street; that street parallel to the Malecón", "Very noisy because of traffic flow; klaxons and braking of cars". "Very irritating near the Ayuntamiento building because of urban buses"; "It is the noisiest location in Puerto Vallarta at any time, because of vendors, traffic flow, nightclubs".

The buses are mostly gas -and possibly some diesel- powered. The sound of buses, and sometimes pick-ups and SUVs, to which the loud music that most of them play adds, predominates. It is the single most important contribution to high sound levels in the city center during the day and part of the night. During the night, the sound of loud music in bars and discotheques contributes to the typical ambiance of the city center, especially in the Malecón. 


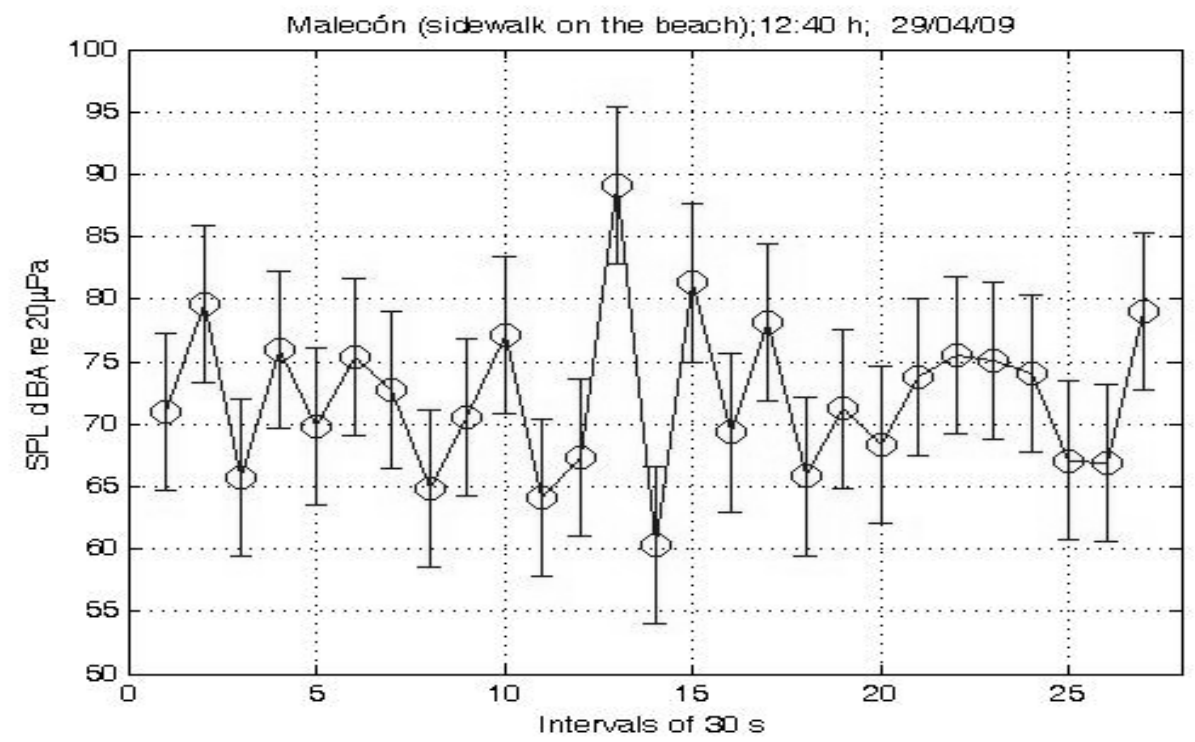

Figure 3. Typical sound levels measured at a point in the Malecón. The periodic peaks are due to the traffic lights and corresponding passage of vehicles.

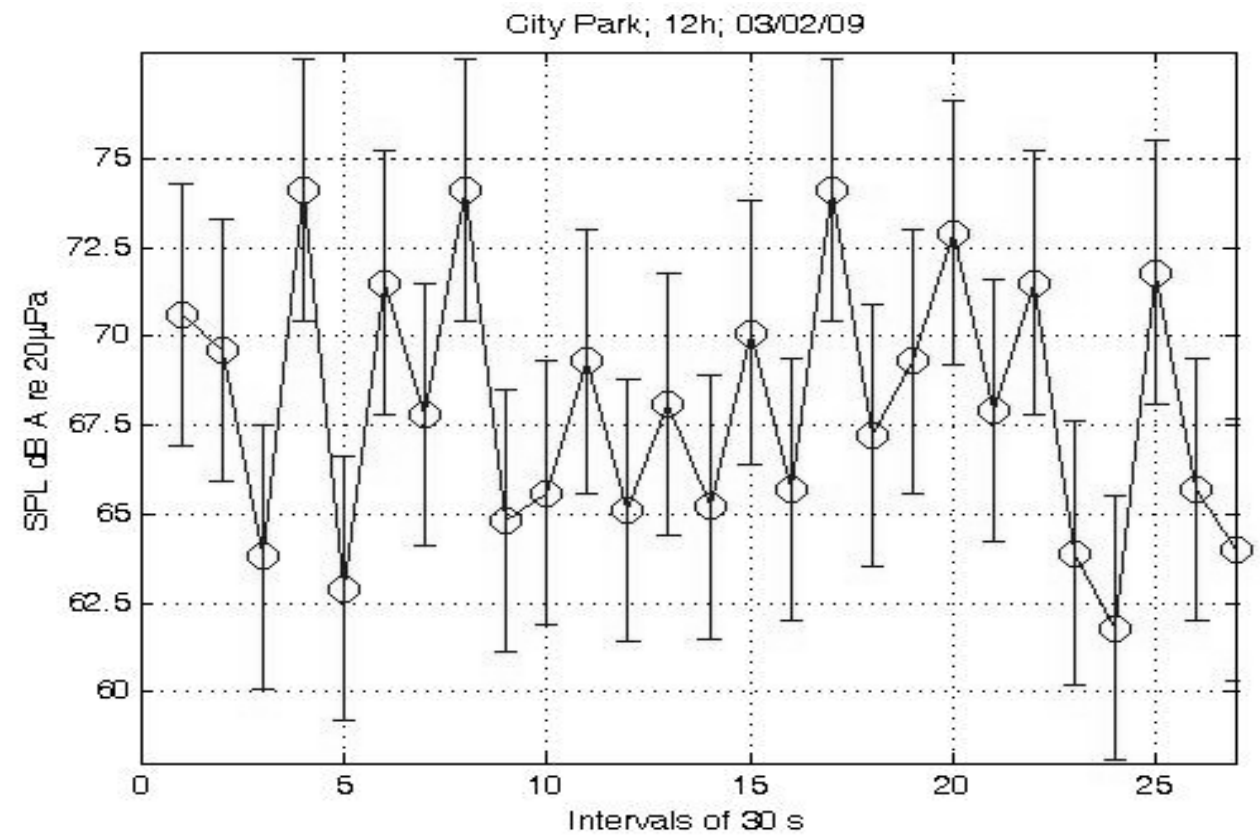

Figure 4. Typical noise levels measured at the City Park. The peaks are produced mostly by the passage of buses and some by the call of birds. 


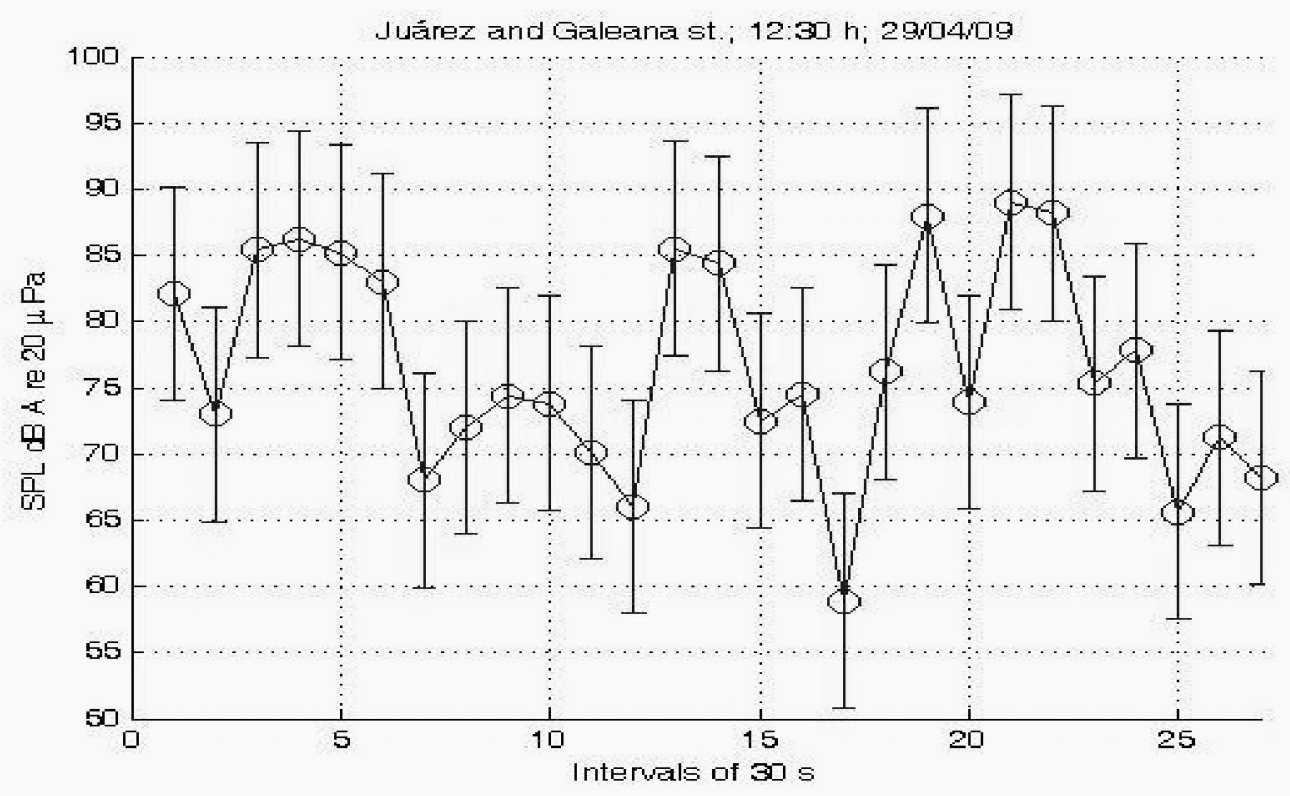

Figure 5. Sound levels typical of any point along the street (Juárez) in the city center.

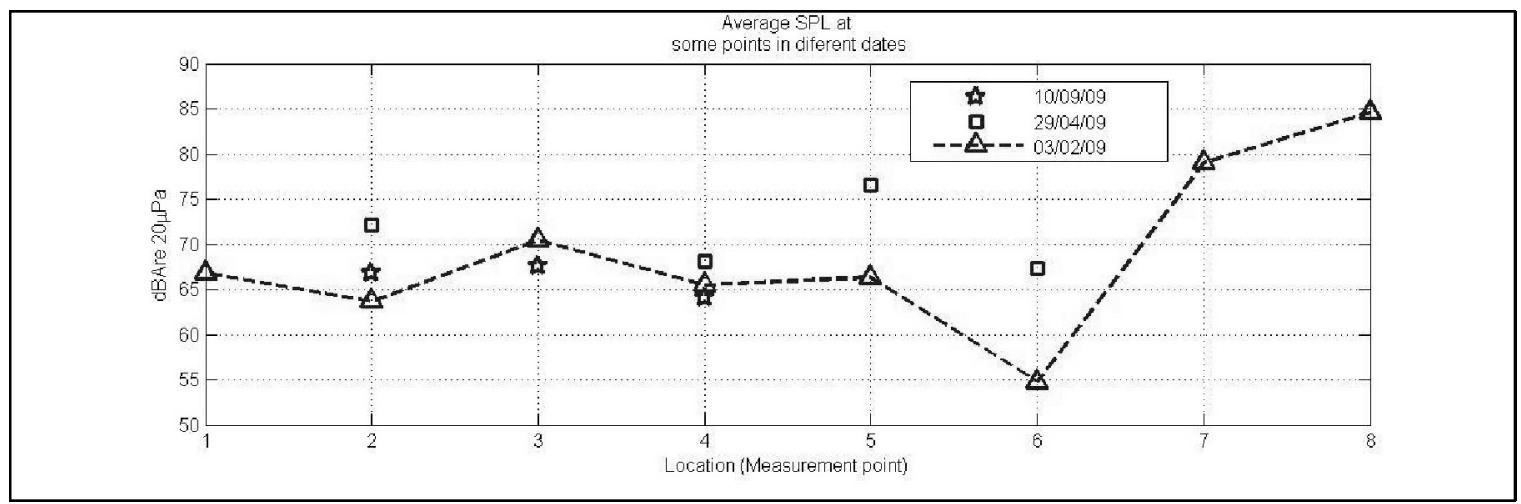

Figure 6. The average values of SPL, measured at all the points described in the main text, at different dates. Note that not all points were measured at the different dates. Point numbers correspond to (1) Las Glorias beach, (2), Rosita Hotel, (3), Malecón, (4), city park, (5), busy Colombia street;(6) residential street near the beach; (7) busy streets corner, Juárez and Galeana, (8) the corner of F. M. Ascencio Avenue, perhaps the busiest main avenue, and Prisciliano Sánchez Street. 
Figure 6, shows the average values at the different locations, some points were measured at different dates. The lowest values of sound levels at midday (average value at around 13:00 hours, was 55 \pm 4 dBA) were measured at locations on the hills surrounding the Banderas bay in Puerto Vallarta.

\section{Discussion}

Due to the difference between the interviewed populations: students and non-students, the answers differ somewhat with respect to the perception of some places. Strangely enough the Malecón zone was mentioned by most of the students as a disagreeable place. This might be due to the fact that many of the students in the CUC come from other towns near Puerto Vallarta, which are quieter or calmer and do not have all this kind of entertainment -on the other hand, maybe too expensive for most of these students- and because some yearning for their hometowns was reflected in their answers.

The main church (Iglesia de Nuestra Señora de Guadalupe), and the sound of the bells were mentioned by non-students as an agreeable place, and an agreeable sound. The city center (referring basically to the streets where buses circulate) was mentioned by both students and non-students as a disagreeable place.

A zone that includes part of the main avenue ( $F$. Medina Ascencio) was referred to by students as the noisiest street in Puerto Vallarta (coincidentally. the highest sound levels were measured in this avenue: 90-92 dBA). The CUC campus was mentioned as an agreeable place with calmed or mixed conditions -two students mentioned the noise of the nearby passage of commercial jets-, by some students. It was mentioned, as expected, only by students. In both populations, the beaches and their sounds were mentioned as agreeable -except when vendors or radios are present-.

The sound of the twittering of the birds is the most mentioned (28 times) sound with a positive connotation, along the sound of the sea waves (27 times), and wind rustling through the trees (21 times). As mentioned many times before (Schaffer 1977), natural sounds are in general agreeable to most people and most of non-natural sounds are disagreeable for most of the 19 people interviewed; the sound of traffic was also one of the most mentioned (30 times) sounds, this time with a negative implication, as noise; the sound of radios along with klaxons, bars and discotheques was mentioned 26 times.

Regarding the concept of peace and tranquility there were 49 different ideas as varied as "respect for people", "decelerated movement of people", "good attitude in people" to "sense of security", "to wake up without the noise from buses..", "without crowds", "clean without garbage", "a quiet place", "good quality of life.", "respect for the environment", etc. Of these ideas only 7 referred specifically to noise.

Finally, the sound level measurements were made in special conditions regarding the world economy crisis -during the whole year of 2009- and the surge of the Influenza AH1N1 in Mexico. The sound level measurements- especially in Aprilwere made in the days where almost all tourism (international and national) activity was very low. This situation might have had some influence on the results; probably if the measurements were to be repeated when normal conditions prevail, the sound levels would be somewhat higher.

\section{Conclusions}

A subjective sound and noise perception survey was made along with an objective noise survey measuring sound levels at different locations and dates-. The ethnographic exploration was done through the application of interviews with the same questions, relating to the noise perception. The interviews were held with two small populations of students and non-students. The results, though possibly limited due to the low number of people interviewed (19) and sound levels measured are representative, firstly, of the thinking of the groups of people interviewed; secondly, of the sound levels one would encounter in the locations surveyed (as corroborated in three different dates). The sound environment (the ensemble of sonic events that are characteristic of a location, district, or a city) of Puerto Vallarta is defined positively mostly in terms of natural sounds, mainly: the sound of sea waves breaking, the sound of birds especially at dawn and the evening- in locations with trees, or the wind rustling through trees. 
Some locations are perceived in mixed terms, sometimes negatively, sometimes positively, depending on the person or the situation. Such places as the city center, in and around the Ayuntamiento park, or the Malecón corresponded to this perception. Some places or streets are definitively perceived as negative such as the streets where the traffic flow is dense (and includes trailers, heavy trucks, etc.) or is mainly due to the circulation of city buses as in the city center, these perceptions agree with the high sound levels measured in those locations. The bells of the main church (Nuestra Señora de Guadalupe) are considered -by non-students mainly- as part of the sonic identity of Vallarta. A periodical event that occurs daily is a pirates show on a replica of the Santa María caravel, around the harbor, that all people in Vallarta identifies as the "pirates ship" because of the sound of firecrackers that irradiates the harbor in front of Puerto Vallarta (what would constitute a sound signature of this cruise).

The concept of peace and tranquility is not specifically linked to sound or noise. Out of 49 ideas that were expressed (9 people), only 7 were related to sound or noise. They were varied and dissimilar but mainly related to quality of live and good relations among people. Finally, the sounds confer to the city -in the population's perceptions- a sonic identity as a result of the sonic signals that people hear and identify as typical of, or belonging to a location. This sonic identity is recognized consciously or unconsciously -the respondents become conscious of these sounds when they are forced to think by the interviewer- as a young interviewee said: "How interesting ...l had never thought of these places in relation to sound." These results point to the fact that there exists awareness, in the inhabitants of Puerto Vallarta, of a sonic environment that they value and are conscious of its changing trends; sometimes for the worse.

\section{References}

[1] Amphoux, P. Sound signatures, configurations and effects, Arch. \& Comport. / Arch and Behav. 3:387-395. 1993.

[2] Augoyard, J. F. The cricket effect. Which tools for the research on sonic ambiances? Conference on Acoustic Ecology. Stockholm, 1-7. 1999.

[3] Barrigón, J. M., V. Gómez, J. A. Méndez, R. VilchesGómez and J. Trujillo. An environmental noise study in the city of Cáceres, Spain. Applied Acoustics. 63:10611070. 2002.

[4] Boullosa, R. R. and S. J. Pérez. An exploratory study of community sound levels in Mexico City, Applied Acoustics, 22(4):271-280. 1987.

[5] Brown, K. A. and C. Lam. Urban noise surveys. Applied Acoustics. 20(1):23-39. 1987.

[6] Canneli, G. B. Traffic noise in Rome. Applied Acoustics. 7:103-115. 1974.

[7] European Commission. Sixth framework programme, sustainable development, global change \& ecosystems integrated project. Silence: Sub- project A "Annoyance". 2008.

[8] Fidell, S. Nationwide urban noise survey. Journal of Acoustical Society of America. 64:198-206. 1978.

[9] López Barrio, I. and J. Carles. Madrid: acoustic dimensions of inhabitated areas: quality criteria, The Soundscape Newsletter. No. 10. 1995.

[10] Massam, B. H., et al. Quality of life in the Puerto Vallarta region of Jalisco, México. Working Paper \#200301. Brandon University, Canada Rural Development Institute. September 2003.

[11] Schaffer, M. R. The tuning of the world, Knopf, New York. 1977.

[12] Velasco, D. Island Landscape: Following in Humboldt's Footsteps through the Acoustic Spaces of the Tropics. Leonardo Music Journal. 10:21-24. 2000.

[13] M. Germán et al. Analysis and evaluation of noise reaction in open public spaces in Mexico City, Acoustics '08, Euronoise, Paris, France. 2008. 


\section{Authors' Biographies}

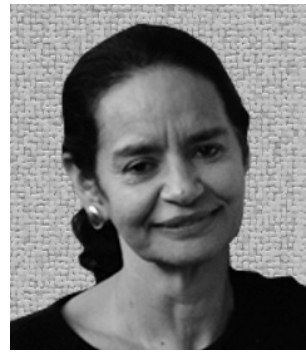

\section{Clara ALVARADO-ZAMORANO}

She is an academic in the Department of Information Technologies at CCADET-UNAM. She earned her bachelor's degree in biochemistry, and a master's degree in pedagogy from Universidad Nacional Autónoma de México, she also earned a master's degree (didactics in experimental sciences), from Universidad de Extremadura, Spain, where she is currently a PhD student. Her research areas of interest are in the didactics of experimental sciences, especially in chemistry and teachers' continuing education. She is leader or participant in various research projects sponsored by CONACYT, UNAM, SEP, Latin American Institute of Educational Communication and Interamerican Development Bank (BID). She has published 5 papers on science teaching, coauthored seven books, and has participated in 27 national and international academic events.

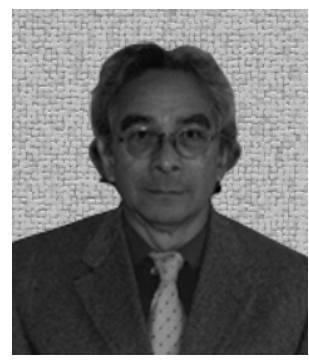

\section{Ricardo RUIZ-BOULLOSA}

He has been a researcher since 1981 at the Acoustics and Vibrations Laboratory, CCADET-UNAM. Has a BSc degree in physics (UNAM, 1972), an MSc degree in sound and vibration (University of Southampton, UK, 1981), and a PhD degree (CIICA-UAEM, Morelos). Dr. Ruiz-Boullosa is founder and chief executive of the design project of the CCADETs' Acoustics Laboratory (1982-1988), head of the Acoustics Laboratory (1988-2000), and initiator of some of its research lines such as the acoustics of the guitar, urban noise, thermoacoustic sources, laser vibration measurements. He has authored and coauthored 35 papers in international journals and 40 papers in national and international congresses, with around 115 citations to his work. He wrote the book "Laser: some demonstrations and simple experiments". He translated the book "Fundamentals of Acoustics," by Kinsler \& Fry. Dr. Ruiz-Boullosa has been supervisor of several theses and is a member of the SNI (National System of Researchers-Level II, 1995). 